Article

\title{
Tuning the $0-0$ bond formation pathways of molecular water oxidation catalysts on electrode surfaces via second coordination sphere engineering
}

\author{
Qiming Zhuo a,†, Shaoqi Zhan ${ }^{\mathrm{b}, \dagger}$, Lele Duan a,c, Chang Liu ${ }^{\mathrm{a}}$, Xiujuan Wu ${ }^{\mathrm{a}}$, Mårten S. G. Ahlquist ${ }^{\mathrm{b}}$, \\ Fusheng $\mathrm{Li}^{\mathrm{a}}{ }^{*}$, Licheng Sun ${ }^{\mathrm{a}, \mathrm{d}}$ \\ a State Key Laboratory of Fine Chemicals, Institute of Artificial Photosynthesis, DUT-KTH Joint Education and Research Centre on Molecular Devices, \\ Institute for Energy Science and Technology, Dalian University of Technology, Dalian 116024, Liaoning, China \\ b Department of Theoretical Chemistry and Biology, School of Engineering Sciences in Chemistry, Biotechnology and Health, KTH Royal Institute of \\ Technology, Stockholm 10691, Sweden \\ c Department of Chemistry and Shenzhen Grubbs Institute, Southern University of Science and Technology (SUSTech), Shenzhen 518055, Guangdong, \\ China \\ d Department of Chemistry, School of Engineering Sciences in Chemistry, Biotechnology and Health, KTH Royal Institute of Technology, Stockholm 10044, \\ Sweden
}

\section{A R T I C L E I N F O}

\section{Article history:}

Received 9 May 2020

Accepted 15 June 2020

Published 5 March 2021

\section{Keywords:}

Water oxidation catalyst

Second coordination sphere

Dipole moment

0-0 bond formation

Reaction kinetics

\begin{abstract}
A B S T R A C T
A molecular [Ru(bda)]-type (bda = 2,2'-bipyridine-6,6'-dicarboxylate) water oxidation catalyst with 4-vinylpyridine as the axial ligand (Complex 1) was immobilized or co-immobilized with 1-(trifluoromethyl)-4-vinylbenzene (3F) or styrene (St) blocking units on the surface of glassy carbon (GC) electrodes by electrochemical polymerization, in order to prepare the corresponding poly-1@GC, poly-1+P3F@GC, and poly-1+PSt@GC functional electrodes. Kinetic measurements of the electrode surface reaction revealed that $[\mathrm{Ru}(\mathrm{bda})]$ triggers the $0-0$ bond formation via (1) the radical coupling interaction between the two metallo-oxyl radicals (I2M) in the homo-coupling polymer (poly-1), and (2) the water nucleophilic attack (WNA) pathway in poly-1+P3F and poly-1+PSt copolymers. The comparison of the three electrodes revealed that the second coordination sphere of the water oxidation catalysts plays vital roles in stabilizing their reaction intermediates, tuning the $0-0$ bond formation pathways and improving the water oxidation reaction kinetics without changing the first coordination structures.
\end{abstract}

(C) 2021, Dalian Institute of Chemical Physics, Chinese Academy of Sciences. Published by Elsevier B.V. All rights reserved.

\section{Introduction}

As an ideal anodic reaction generating electrons and protons, water oxidation is at the core of the conversion and stor- age of renewable energy into hydrogen or other chemicals [1-4]. However, the water oxidation reaction requires the release of four protons and four electrons from two water molecules, along with the formation of an $0-0$ bond, which is an

\footnotetext{
*Corresponding author. Tel/Fax: +86-411-84986494; E-mail: fusheng@dlut.edu.cn

† These authors contributed equally to this work.

This work was supported by the Fundamental Research Funds for the Central Universities (DUT19LK16), the Natural Science Foundation of China (21120102036, 91233201, 21771098), the National Basic Research Program of China (973 program, 2014CB239402), the State Key Laboratory of Fine Chemicals (KF1802), the Swedish Research Council (2017-00935), the Swedish Energy Agency, and the K \& A Wallenberg Foundation. DOI: 10.1016/S1872-2067(20)63671-3 | http://www.sciencedirect.com/science/journal/18722067| Chin. J. Catal., Vol. 42, No. 3, March 2021
} 
energetically demanding and mechanistically complicated reaction with a slow kinetics $[5,6]$. Therefore, it is crucial to develop efficient water oxidation catalysts (WOCs) to accelerate the reaction $[7,8]$.

Molecular WOCs have attracted much attention owing to the facile tunability of their structural and electronic properties, as well as the ability to mediate multiple proton-electron transfer reactions, which can facilitate comprehensive mechanistic studies [9-11]. However, approaches for the rational design of WOCs and the systematic improvement of catalytic reactivity are poorly understood, which remains a fundamental challenge in order to achieve efficient $0-0$ bond formation under mild conditions. The $\mathrm{O}-\mathrm{O}$ bond formation is often the crucial rate-determining step (RDS) for most WOCs [10], which is mainly due to the challenging requirement of bringing the two oxygen atoms in close proximity to each other, in order to form the $\mathrm{O}-\mathrm{O}$ bond in water oxidation systems [12].

Generally, two mechanistic scenarios for the 0-0 bond formation are well accepted in water oxidation chemistry (Scheme 1). One involves the $0-0$ radical coupling of two metallo-oxyl species (I2M), which results in the formation of a peroxo bridge between the two metal centers. The other involves water nucleophilic attack (WNA) on the metal-oxo species with simultaneous proton transfer to a proton acceptor to generate a metal-hydroperoxide intermediate.

The key differences between these two scenarios are: (1) the WNA pathway is a single-site reaction, whereas the I2M pathway involves two reaction sites; (2) the WNA pathway involves a proton transfer in the $0-0$ bond formation step, whereas in the I2M pathway this step does not involve a proton transfer. When the $\mathrm{O}-\mathrm{O}$ bond formation is the RDS, two conclusions can be drawn based on the above key differences: (1) when WOCs immobilized on the electrode surface react via the WNA pathway, a first-order relationship exists between catalytic current and WOC loading, due to the single-site reaction feature; the functional electrode displays primary H/D kinetic isotope effects $\left(\mathrm{KIE}_{\mathrm{H} / \mathrm{DS}}\right)$, due to the proton transfer involved in this process, and the catalytic current at the electrode will be sensitive to the concentration of the anions functioning as proton acceptors in the buffer; (2) on the other hand, when WOCs operate via the I2M pathway on the electrode surface, the generated catalytic current will exhibit a second-order relationship with the catalyst loading; the electrode will not display KIEH/DS, and the overall rate of water oxidation is likely to be insensitive to the buffer concentration.

Since the pioneering report on the blue dimer by Meyer and co-workers in the 1980s [13], considerable efforts have been devoted to improving the catalytic activity of molecular WOCs
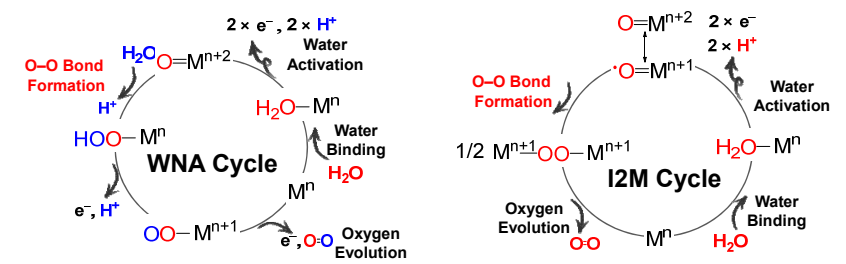

Scheme 1. Overview of oxo-oxo coupling (I2M) and water nucleophilic attack (WNA) mechanisms for $0-0$ bond formation by WOCs. by tuning their first coordination environments [9-14]. The immobilization of molecular WOCs on the surface of electrodes is an important task in water oxidation technologies, which require the use of functional electrodes [15-17]. Unfortunately, the effect of the second coordination sphere (or outer coordination environment) of immobilized molecular WOCs on their catalytic activities has not yet been fully elucidated, as the chemical environments of these catalysts on the electrodes are quite different from those in solution.

The photosystem II (PSII) in green plants is known to exhibit excellent water oxidation activity, and its active center, the so-called oxygen-evolving complex (OEC), consists of a $\mathrm{Mn}_{4} \mathrm{CaO}_{5}$ cluster surrounded by hydrogen-bond networks $[18,19]$. In the OEC, the oxidation of the $\mathrm{Mn}_{4} \mathrm{CaO}_{5}$ cluster is directly coupled with proton transfer processes. However, the water molecule is a weak proton acceptor [20]; as a consequence, the chemical environment in the second coordination sphere of $\mathrm{Mn}_{4} \mathrm{CaO}_{5}$ is known to play a vital role in the proton transfer processes during water oxidation $[21,22]$. For instance, the electric field arising from the positive charge at $\mathrm{Y}_{\mathrm{Z}^{+}}$ (Tyr160/161) species affects the $\mathrm{pKa}$ values of bound water and promotes proton hopping steps, eventually resulting in a process that transfers the protons from the OEC to the aqueous phase [23]. The dipole moment environments of PSII are considered as critical parameters of the electron-transfer processes for water oxidation [24-26]. These findings suggest that, in artificial water oxidation catalysis, the 'smart' removal of protons and electrons from the catalytic site should also be considered as an essential issue.

In this work, we studied the effects of the second coordination sphere (or outer coordination environment) of immobilized molecular WOCs on the $\mathrm{O}-\mathrm{O}$ bond formation mechanism and catalytic activity, which is vital for the rational design and development of electrode devices.

\section{Experimental}

\subsection{Materials and instrumentation}

Unless otherwise stated, all chemicals and solvents were purchased from Sigma Aldrich and used without further purification; water used in syntheses and measurements was deionized by the Milli-Q technique. Complex $\mathbf{1}$ was prepared via a simple one-pot reaction [27]. NMR spectra were recorded on a Bruker Advance 500 spectrometer. Mass spectrometry measurements were performed on a Finnigan LCQ Advantage MAX spectrometer.

\section{2. $\quad$ Electrochemical measurements}

All electrochemical measurements were carried out in a three-electrode system using a standard cell connected to a CHI 760 e electrochemical workstation. Platinum foil was employed as the counter electrode. The reference electrodes were $\mathrm{Ag} / \mathrm{AgCl}$ (in $3 \mathrm{M} \mathrm{KCl}$ ) for aqueous solutions or $\mathrm{Ag} / \mathrm{AgNO}_{3}$ (in 0.1 $\mathrm{M} \mathrm{AgNO}_{3}$ ) for non-aqueous solutions. All potentials measured in the aqueous phase were converted to the normal hydrogen 
electrode (NHE) scale using the $\left[\mathrm{Ru}(\mathrm{bpy})_{3}\right]^{2+} /\left[\mathrm{Ru}(\mathrm{bpy})_{3}\right]^{3+}$ couple $\left(E_{1 / 2}=1.26 \mathrm{~V} v s\right.$. NHE) as an external reference. All measured potentials were converted to the NHE scale according to the relation $E_{\mathrm{NHE}}=E_{\mathrm{Ag} / \mathrm{AgCl}}+0.197 \mathrm{~V}$.

\subsection{Electropolymerization}

The preparation of the poly-1@GC electrode was carried out according to the method described by Meyer [28]. Glassy carbon (GC) working electrodes $(\Phi=3 \mathrm{~mm}$ ) were cycled in an acetonitrile solution containing $0.5 \mathrm{mM}$ complex 1 and $0.1 \mathrm{M}$ $\mathrm{TBAPF}_{6}$, in successive scans from 0 to $-2.4 \mathrm{~V}$ (vs. $\mathrm{Ag} / \mathrm{AgNO}_{3}$ ). The resulting electrodes were rinsed with ethanol and dried by $\mathrm{N}_{2}$ flow. All solutions were deaerated with argon for $10 \mathrm{~min}$ before electropolymerization. The poly-1+P3F@GC and poly-1+PSt@GC electrodes were prepared following the same procedures employed for the poly-1@GC electrode. The electrodeposition solutions contained $12.5 \quad \mathrm{mM}$ 1-(trifluoromethyl)-4-vinylbenzene or styrene as the blocking units.

Other experimental details can be found in the Supporting Information.

\section{Results and discussion}

The [Ru(bda) $\left.\mathrm{L}_{2}\right]$-type molecular WOCs $\left(\mathrm{bda}^{2-}=\right.$ 2,2'-bipyridine-6,6'-dicarboxylate; $\mathrm{L}=\mathrm{N}$-cyclic aromatic ligand) have displayed high water oxidation activities in the presence of the Ce $\mathrm{IV}^{\mathrm{IV}}$-based chemical oxidant $\left(\mathrm{NH}_{4}\right)_{2} \mathrm{Ce}\left(\mathrm{NO}_{3}\right)_{6}$ in acidic aqueous solutions ( $\mathrm{pH}$ 1.0). The [Ru(bda) $\left.\mathrm{L}_{2}\right]$ compounds catalyze water oxidation through the I2M pathway, in which the 0-O bond formation is the RDS [29-33]. To explore the influence of the outer coordination environment (such as the distance between the catalyst centers and the dipole environments) or the effect of proton acceptors on the $\mathrm{O}-\mathrm{O}$ bond formation mechanisms, we chose a molecular [Ru(bda)L2]-type WOC bearing 4-vinylpyridine axial ligands (Complex 1) as the model catalyst. In a previous study, Complex 1 was immobilized on the surface of $\mathrm{TiO}_{2}$ electrodes using electrochemical polymerization methods for light-driven water oxidation $[27,28]$. The same strategy was employed in this work to immobilize Complex $\mathbf{1}$ on the surface of a GC electrode (poly-1@GC). In addition, Complex 1 was copolymerized with 25 equivalents of either styrene (St) or 1-(trifluoromethyl)4-vinylbenzene $(3 \mathrm{~F})$ to yield the functional electrodes poly-1+PSt@GC and poly-1+P3F@GC, respectively.

As shown in Scheme 2, the difference between poly-1@GC

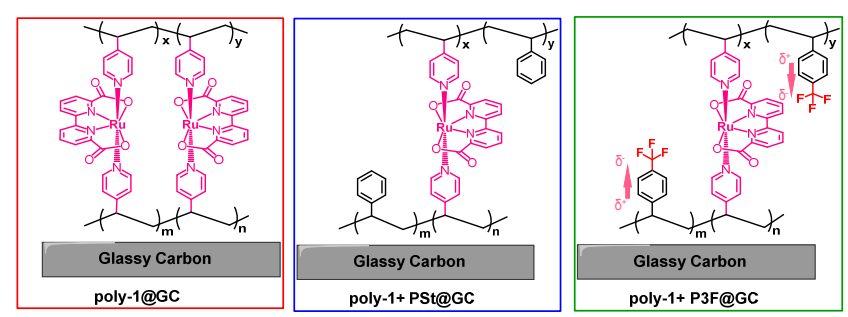

Scheme 2. Schematic diagrams of electrodes prepared via electrochemical polymerization. and poly-1+PSt@GC is the presence of the polystyrene (PSt) blocking units in the latter, which separates the [Ru(bda)] units from each other and thereby inhibits the direct coupling interaction between the two Ru-oxyl radicals. In contrast, the probability of the homo-coupling of [Ru(bda)] is higher in the single polymer-immobilized electrode poly-1@GC. Therefore, the analysis of the poly-1@GC and poly-1+PSt@GC samples could reveal the influence of the distance between the catalytic centers on the $\mathrm{O}-\mathrm{O}$ bond formation mechanisms, and provide an opportunity to measure the water oxidation reaction rates of a catalyst in two different pathways.

The 4-(trifluoromethyl)-phenyl groups in poly-1+P3F@GC, with a larger dielectric constant, provide a much stronger dipole environment surrounding the $[\mathrm{Ru}(\mathrm{bda})]$ units than that created by the phenyl groups in poly-1+PSt@GC. [Ru(bda)] is known to form intermediates with charge +1 in the reaction. The strong dipole environment in poly-1+P3F@GC will stabilize the charged intermediates and influence the reaction rates $[34,35]$. At the same time, C-F bonds can serve as hydrogen-bonding acceptors and are widely used in bio-organic chemistry and medicine [36-39]. Therefore, when $\mathrm{C}\left(s p^{3}\right)-\mathrm{F}$ groups are introduced in the second coordination sphere of a WOC without altering its first coordination structure, the comparison of poly-1+P3F@GC and poly-1+PSt@GC electrodes will help to explore the effect of the dipole environment on the water oxidation reaction, which has been rarely investigated; in addition, the comparison may also reveal the influence of hydrogen-bonding acceptors surrounding the WOC on its water oxidation kinetics.

The cyclic voltammetry (CV) curves of the three electrodes show large catalytic currents in solutions at $\mathrm{pH} 7.0$, with an onset potential at around $1.25 \mathrm{~V} v$ s. NHE (Fig. S1, see electronic supporting information, the same below). The differential pulse voltammetry (DPV) curves (Fig. S2) show that poly-1@GC exhibited $\mathrm{Ru}^{\mathrm{III} / \mathrm{II}}, \mathrm{Ru}^{\mathrm{IV} / \mathrm{III}}$, and $\mathrm{Ru}{ }^{\mathrm{V} / \mathrm{IV}}$ redox potentials of $0.64,0.82$, and $1.07 \mathrm{~V} v s$. NHE, respectively, which are close to those of the poly-1+PSt@GC electrode $\left(\mathrm{Ru}^{\mathrm{III} / \mathrm{II}}, \mathrm{Ru}^{\mathrm{IV} / \mathrm{III}}\right.$, and $\mathrm{Ru}{ }^{\mathrm{V} / \mathrm{IV}}$ potentials of $\sim 0.62,0.83$, and $1.08 \mathrm{~V} v s$. NHE, respectively). The fluorinated poly-1+P3F@GC showed $\mathrm{Ru}^{\mathrm{III} / \mathrm{II}}, \mathrm{Ru}^{\mathrm{IV} / \mathrm{II}}$, and $\mathrm{Ru} / \mathrm{IV}$ redox potentials of $0.56,0.82$, and $1.02 \mathrm{~V} v s$. NHE, respectively, which are lower compared to the redox potentials of the other two electrodes.

The Pourbaix diagrams of the three electrodes were constructed on the basis of their DPV curves at various $\mathrm{pH}$ values (Fig. 1). In the Pourbaix diagrams, poly-1@GC and poly-1+PSt@GC exhibited very similar pH-dependent redox properties, and the potentials of their corresponding redox species showed minor differences at the same $\mathrm{pH}$. In contrast, poly-1+P3F@GC exhibited significantly different pH-dependent redox properties. The $\mathrm{Ru}^{\mathrm{III}} / \mathrm{Ru}^{\mathrm{II}}$ redox potentials of poly-1@GC and poly-1+PSt@GC were pH-independent below pH 5.7 $\left(\mathrm{Ru}^{\mathrm{III}}-\mathrm{H}_{2} \mathrm{O} / \mathrm{Ru}^{\mathrm{II}}+\mathrm{H}_{2} \mathrm{O}\right)$ and became $\mathrm{pH}$-dependent in the $\mathrm{pH}$ 5.7-11 region, with a proton-coupled electron transfer (PCET) process from $\mathrm{Ru}^{\mathrm{II}}+\mathrm{H}_{2} \mathrm{O}$ to $\mathrm{Ru}^{\mathrm{III}}-\mathrm{OH}$ (the heptacoordinated $\mathrm{Ru}^{\mathrm{II}}-\mathrm{H}_{2} \mathrm{O}$ species does not exist, according to our previous study) [40]. Such turning point for the PCET process was shifted to $\mathrm{pH} 6.0$ in the case of poly-1+P3F@GC, and the redox po- 

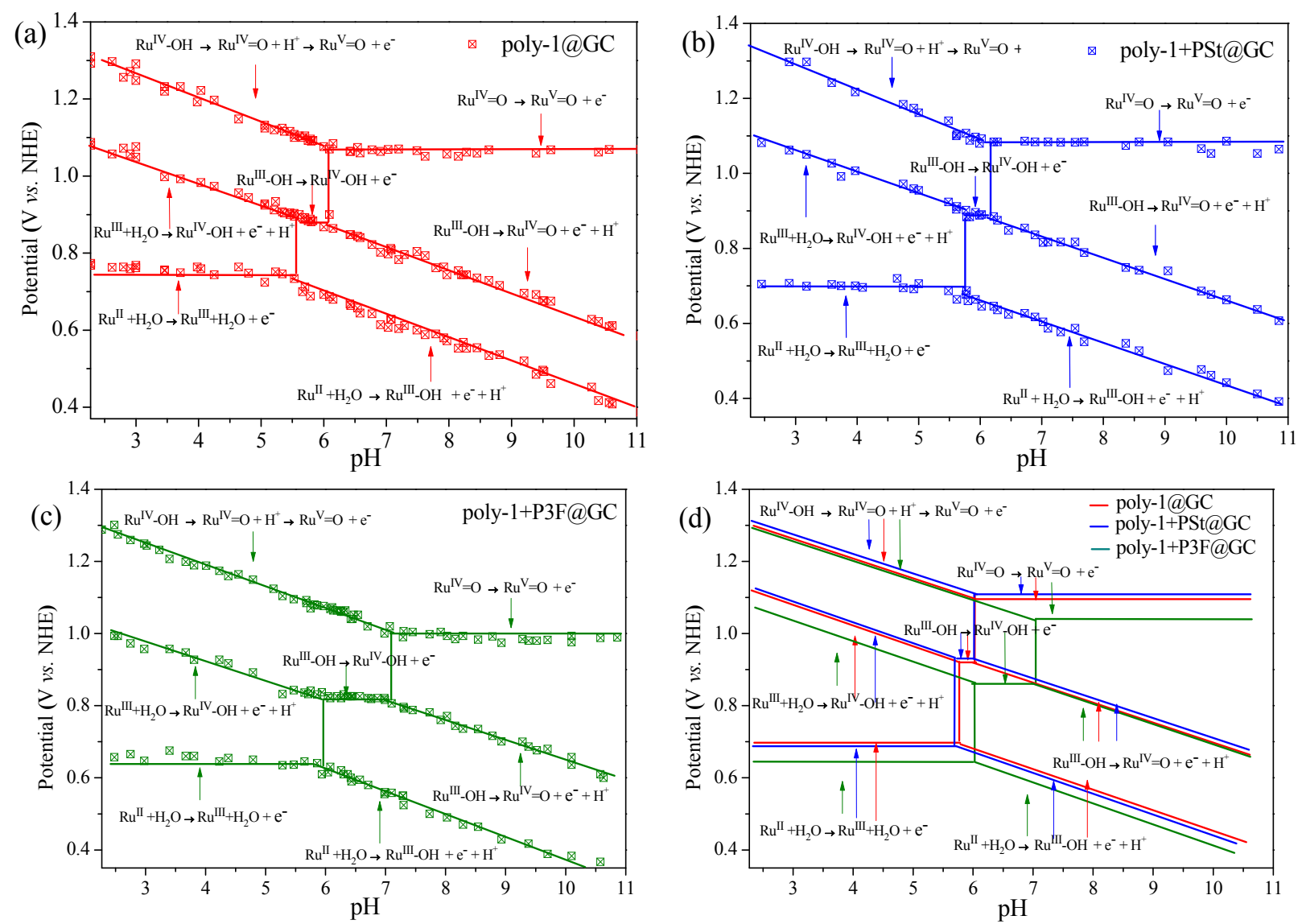

Fig. 1. Pourbaix diagrams of poly-1@GC (a), poly-1+PSt@GC (b), and poly-1+P3F@GC (c) electrodes; (d) simulated Pourbaix diagrams of the three electrodes.

tential of the $\mathrm{Ru}^{\mathrm{III} / \mathrm{II}}$ couple was shifted in the negative direction compared to those of poly-1@GC and poly-1+PSt@GC at the same pH (Fig. 1(d)). For the Ru ${ }^{\mathrm{IV} / \mathrm{III}}$ couple, each of poly-1@GC and poly-1+PSt@GC displayed two one-electron/one-proton PCET processes in the pH ranges from 2 to 5.7 and 6.0 to 11 , along with a one-electron process in the $\mathrm{pH}$ range from 5.7 to 6.0; these $\mathrm{pH}$ ranges corresponded to the $\mathrm{Ru}^{\mathrm{IV}}-\mathrm{OH} / \mathrm{Ru}^{\mathrm{III}}-\mathrm{OH}_{2}$, $\mathrm{Ru}^{\mathrm{IV}}=\mathrm{O} / \mathrm{Ru}^{\mathrm{III}}-\mathrm{OH}$, and $\mathrm{Ru}^{\mathrm{IV}}-\mathrm{OH} / \mathrm{Ru}^{\mathrm{III}}-\mathrm{OH}$ processes, respectively. On the other hand, in the poly-1+P3F@GC system, the three processes were located in the $\mathrm{pH}$ ranges of 2 to $6.0,7.1$ to 11 , and 6.0 to 7.1, respectively. Again, the [Ru(bda)] units in poly-1+P3F@GC displayed clear negative shifts for the $\mathrm{Ru}^{\mathrm{IV}}-\mathrm{OH} / \mathrm{Ru}^{\mathrm{III}}-\mathrm{OH}_{2}$ and $\mathrm{Ru}^{\mathrm{IV}}-\mathrm{OH} / \mathrm{Ru}^{\mathrm{III}}-\mathrm{OH}$ processes at the same $\mathrm{pH}$. In the case of the $\mathrm{Ru}^{\mathrm{V} / \mathrm{IV}}$ states, the oxidation of $\mathrm{Ru}^{\mathrm{IV}}=\mathrm{O}$ to $\mathrm{Ru}^{\mathrm{V}}=\mathrm{O}$ proceeded at $\mathrm{pH}>6.0$, while the $\mathrm{Ru}^{\mathrm{V}}=\mathrm{O} / \mathrm{Ru}^{\mathrm{IV}}-\mathrm{OH}$ process took place at $\mathrm{pH}<6.0$ in poly-1@GC and poly-1+PSt@GC. For the poly-1+P3F@GC electrode, the turning point was shifted to $\mathrm{pH} 7.1$, with clear negative shifts in the $\mathrm{Ru}^{\mathrm{V}}=\mathrm{O} / \mathrm{Ru}^{\mathrm{IV}}=0$ redox potential.

The negative shifts of the redox potentials of $[\mathrm{Ru}(\mathrm{bda})]$ in poly-1+P3F@GC suggest that the catalytic centers were considerably influenced by the trifluoromethyl groups in the second coordination spheres of the catalysts. This influence is unlikely to reflect a direct covalent bonding effect, since the direct bonding of the electron-withdrawing group to the catalyst will reduce the electron density of [Ru(bda)], leading to a positive shift of the redox potentials. We noticed that P3F had a stronger influence on the redox processes involving charged products, such as $\left[\mathrm{Ru}^{\mathrm{III}}-\mathrm{H}_{2} \mathrm{O}\right]^{+} /\left[\mathrm{Ru}^{\mathrm{II}}+\mathrm{H}_{2} \mathrm{O}\right]^{0},\left[\mathrm{Ru}^{\mathrm{IV}}-\mathrm{OH}\right]^{+} /\left[\mathrm{Ru}^{\mathrm{III}}-\mathrm{OH}\right]^{0}$, and $\left[\mathrm{Ru}^{V}=0\right]^{+} /\left[\mathrm{Ru}^{\mathrm{IV}}=0\right]^{0}$, which is attributed to the strong dipole moment of the 4-(trifluoromethyl)-phenyl group. The dielectric constant of the 4-(trifluoromethyl)-phenyl group is 9.18, much higher than that of the phenyl group (2.47) [41]. In solution, the 4-(trifluoromethyl)-phenyl group with a strong dipole moment can interact with and stabilize the [Ru(bda)] intermediates bearing partial charges; the 4-(trifluoromethyl)- phenyl group can also stabilize the protons of the polarized $\mathrm{O}-\mathrm{H}$ bonds in the PCET steps and therefore facilitate the deprotonation process [34,35]. Density functional theory (DFT) calculations were used to investigate the influence of the 4-(trifluoromethyl)-phenyl group on the free energies of the redox processes. In the optimized geometries, a 4-(trifluoromethyl)-phenyl group was located close to the catalytic center of the $[\mathrm{Ru}(\mathrm{bda})]$ catalysts, producing a favorable interaction. The results of the DFT calculations show that the redox potential of the $\mathrm{Ru}^{\mathrm{IV}}-\mathrm{OH} / \mathrm{Ru}^{\mathrm{III}}-\mathrm{H}_{2} \mathrm{O}$ couple for [ $\left.\mathrm{Ru}(\mathrm{bda})\right]$ units with an adjacent 4-(trifluoromethyl)-phenyl group is significantly lower $(1.20 \mathrm{eV})$ than that of bare [Ru(bda)] (1.29 eV); moreover, the redox potential for the $\mathrm{Ru}=\mathrm{V}=/ \mathrm{Ru}^{\mathrm{IV}}-\mathrm{OH}$ process with a 4-(trifluoromethyl)-phenyl group in close proximity 
$(1.59 \mathrm{eV})$ is slightly lower than that of bare [Ru(bda) $](1.60 \mathrm{eV})$. The calculated results are in line with the experimentally determined values of the negative shifts of the redox potentials.

To further examine the $\mathrm{O}_{2}$ evolution of the [Ru(bda)] catalyst in the polymers and copolymers, rotating ring-disk electrode (RRDE) measurements were conducted to directly evaluate the correlation between applied potential and $\mathrm{O}_{2}$ evolution. As shown in Fig. S3, we applied a potential of $-0.22 \mathrm{~V} v$ s. NHE, which was sufficient to promote the oxygen reduction reaction (ORR) on the Pt-ring electrode in a diffusion-limited regime (Fig. S3(d)). In the RRDE experiments, a polished GC disk electrode was modified with the $[\mathrm{Ru}(\mathrm{bda})]$ catalyst. At approximately $1.05 \mathrm{~V}$ vs. NHE, the linear sweep voltammetry (LSV) curve shows an increase in the anodic current of poly-1@GC (Fig. S3(a)), which can be attributed to the formation of the $\mathrm{Ru}^{\mathrm{V}}=\mathrm{O}$ species and to the catalytic water oxidation. Correspondingly, the ORR current on the Pt-ring electrode could be observed as long as the potential applied to poly-1@GC was high enough to generate $\mathrm{Ru}^{\mathrm{V}}=0$, suggesting that the water oxidation reaction was triggered by the $\mathrm{Ru}^{\mathrm{V}}=\mathrm{O}$ species of poly-1@GC, which is in line with reported mechanistic studies of [Ru(bda)]-based WOCs [9,14]. The same phenomenon was observed for poly-1+PSt@GC and poly-1+P3F@GC (Figs. S3(b) and $\mathrm{S} 3(\mathrm{c})$ ). Although the $\mathrm{Ru}=\mathrm{V}=\mathrm{O}$ species triggered the $\mathrm{O}_{2}$ evolution in the three electrodes, the intermediates and redox processes involved were quite different. At $\mathrm{pH}=7$, the oxidation of $\mathrm{Ru}^{\mathrm{III}}-\mathrm{OH}$ yielded $\mathrm{Ru}^{\mathrm{IV}}=0$ for both poly-1@GC and poly-1+PSt@GC, while $\mathrm{Ru}^{\mathrm{IV}}-\mathrm{OH}$ was generated from poly-1+P3F@GC, indicating that the presence of the 4-(trifluoromethyl)-phenyl functional group in the second coordination sphere has significant influence on both the reaction intermediates and the catalytic cycle of the WOCs. In addition, the negative shift of the potential for the $\mathrm{Ru}^{\mathrm{V}}=\mathrm{O}$ generation process in poly-1+P3F@GC may also influence the reaction rate.

Then, a series of measurements were performed to study the influence of functional groups in the second coordination spheres on the reaction kinetics. The analysis of the differences between the I2M and WNA pathways has revealed that the rates of single-site catalysts operating via the WNA pathway have a first-order dependence on the catalyst, while a second-order dependence was found for the I2M mechanism [10]. The $\mathrm{KIE}_{\mathrm{H} / \mathrm{D}}$ is used to examine the kinetics of water oxidation reactions and determine the RDS of the catalytic processes [42-44]. The presence of $\mathrm{KIEH} / \mathrm{DS}$ indicates that the RDS involves a proton transfer, while the absence of $\mathrm{KIE}_{\mathrm{H} / \mathrm{DS}}$ is widely accepted as indicating lack of proton transfer in the RDS [45]. The WNA pathway distinctly involves proton transfer, and the reaction usually displays primary isotope effects, typically with $\mathrm{KIEH}_{\mathrm{H}} \mathrm{D}$ values above 2 [42-44]. When the RDS does not involve proton transfer processes, such as the dimerization of the two $\mathrm{Ru}^{\mathrm{V}}=\mathrm{O}$ units, $\mathrm{KIE}_{\mathrm{H} / \mathrm{D}}$ is usually between 0.7 and $1.5[46,47]$. In the WNA pathway, the $\mathrm{O}-\mathrm{O}$ bond formation step can be accelerated by increasing the effective concentration of the proton acceptor, which can facilitate the formation of the metal-hydroperoxide species. This phenomenon does not necessarily require a change in $\mathrm{pH}$ and takes place through the so-called atom-proton transfer (APT) $[21,48]$. Furthermore, the APT with the phosphate group serving as a proton acceptor can reduce the barrier of the $0-0$ bond formation step and increase the activity of catalysts that operate via the WNA pathway. Therefore, the reaction orders of the catalysts $\left(\rho_{\Gamma}\right)$ on the electrode surfaces, the KIEH/D values, and the reaction orders of the phosphate anion $\left(\rho_{[\mathrm{P} i]}\right)$ in the buffer solution were examined to study the water oxidation kinetics of the poly-1@GC, poly-1+P3F@GC, and poly-1+PSt@GC electrodes. Related derivations and explanations are provided in the Supplementary Information.

As shown in Fig. S4, the high Faraday efficiencies of the poly-1@GC, poly-1+PSt@GC, and poly-1+P3F@GC electrodes (calculated by eqn. S1) indicate that the accumulated charges passing through the electrodes were almost quantitatively consumed for the water oxidation, and therefore the corresponding catalytic currents of the electrodes were directly used for the kinetic analysis. By controlling the time of polymerization or scan numbers of the CV experiments, electrodes with various $\Gamma$ values were obtained (Fig. S5). The reaction orders of the catalyst ( $\left.\rho_{\text {cata }}\right)$ can be calculated from eqns. S2-S7. The anodic current increased with increasing $\Gamma$ under the same conditions, and the $\rho_{\text {cata }}$ values for poly-1@GC were calculated. The resulting $\rho_{\text {cata }}$ value was approximately 2 at different applied potentials (Fig. 2(a)), indicating a second-order reaction kinetics for poly-1@GC, and thus an I2M pathway for the 0-0 bond formation. By keeping the catalyst coverage of poly-1@GC constant and changing $\mathrm{H}_{2} \mathrm{O}$ to $\mathrm{D}_{2} \mathrm{O}$, we compared the LSV curves of poly-1@GC in $\mathrm{H}_{2} \mathrm{O}$ and $\mathrm{D}_{2} \mathrm{O}$ solutions (Fig. 2(b)). The $\mathrm{KIE}_{\mathrm{H} / \mathrm{D}}$ values calculated according to eqns. S8-S11 were approximately 1.15 , which is within the range of secondary isotope effects (1.1 to $1.4 \mathrm{~V}$ ), suggesting that the RDS for the poly-1@GC electrode does not involve $0-\mathrm{H}$ bond cleavage. By keeping $\Gamma$ and other parameters constant, while varying the concentration of phosphate buffer alone $\left(\mathrm{Na}_{2} \mathrm{SO}_{4}\right.$ salt was added to maintain an ionic strength of $0.1 \mathrm{M}$ ), we recorded the LSV curves of poly-1@GC at different phosphate concentrations (Fig. 2(c)), and calculated the reaction orders of phosphate $\left(\rho_{\mathrm{pi}}\right)$ by eqn. $\mathrm{S} 2$. The results reveal a zero-order reaction kinetics of phosphate for poly-1@GC, which indicates that the phosphate ions are not involved in the RDS. Overall, based on the obtained $\rho_{\text {cata, }} \rho_{\mathrm{pi}}$, and $\mathrm{KIEH}_{\mathrm{H}} \mathrm{D}$ values, we concluded that poly-1@GC catalyzes water oxidation mainly through the I2M pathway.

The $\rho_{\text {cata, }} \rho_{\mathrm{pi}}$, and $\mathrm{KIE}_{\mathrm{H} / \mathrm{D}}$ values of poly-1+PSt@GC were measured using the same methods, and the results suggest that a first-order reaction takes place on the catalyst (Fig. 3(a)), indicating that single-site WNA is the major pathway for $[\mathrm{Ru}(\mathrm{bda})]$ in the co-polymer electrode. The $\mathrm{KIEH/D}$ value is larger than 2.4 in the range of 1.1 to $1.4 \mathrm{~V}$ (Fig. 3(b)), which clearly indicates the presence of primary isotope effects and $\mathrm{O}-\mathrm{H}$ bond cleavage in the RDS [27]. The reaction orders in phosphate concentration were greater than 0.2 (Fig. 3(c)), showing that the reaction rate increased with increasing phosphate concentration, confirming the occurrence of the APT process in the RDS for [Ru(bda)] in the co-polymer electrode. These results reveal that the WNA pathway is active for poly-1+PSt@GC. In the case of poly-1@GC, the polymerization 

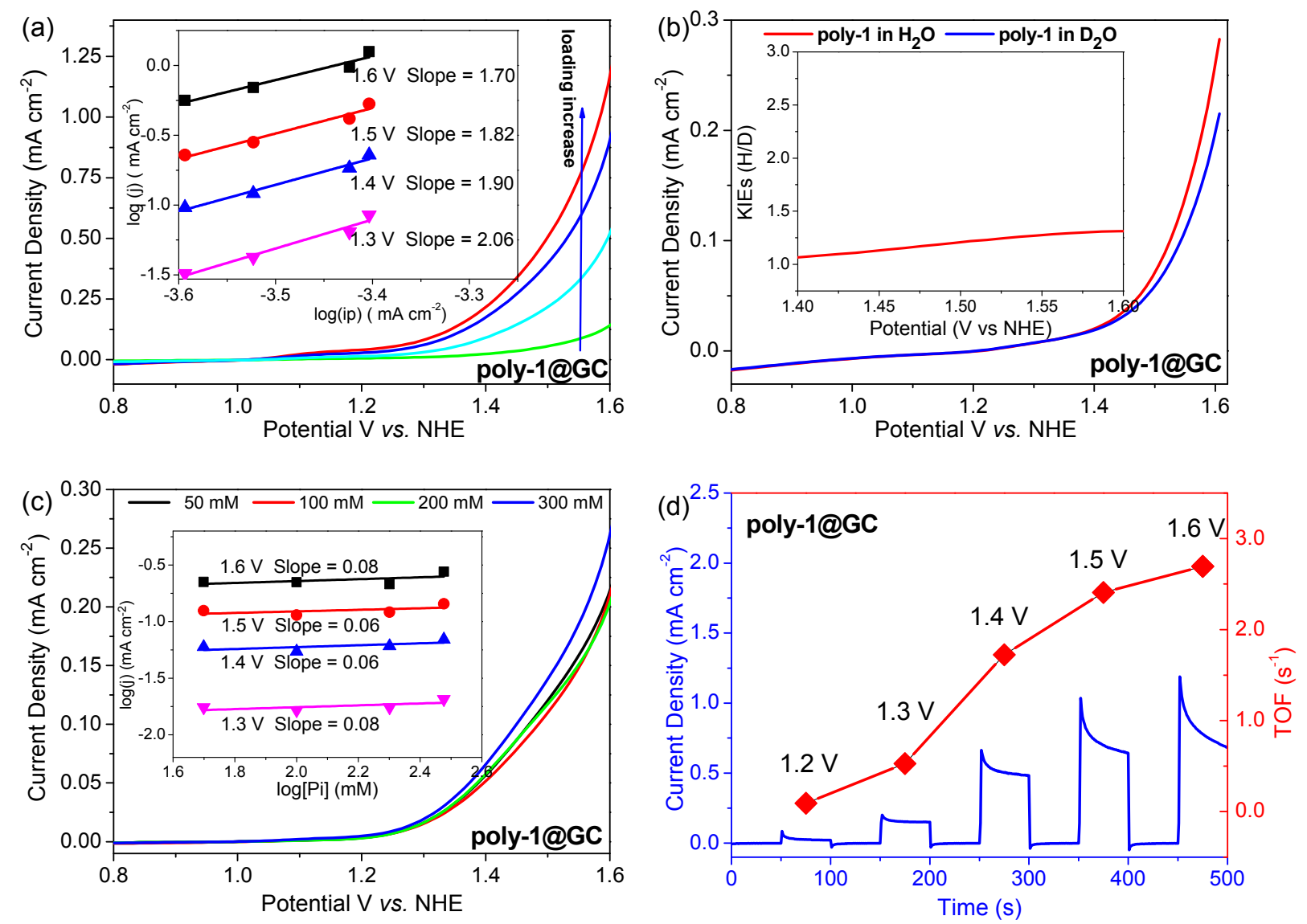

Fig. 2. (a) LSV curves of poly-1@GC at various catalyst coverages $(\Gamma)$. The inset plot shows the logarithm of the current density at selected potentials against the logarithm of the corresponding peak current of the $\mathrm{Ru} \mathrm{u}^{\mathrm{III} / \mathrm{II}}$ couple; the slopes of the linear fitting curves reflect the reaction orders in catalyst coverage $\left(\rho_{\Gamma}\right)$. (b) LSV curves of poly-1@GC in $\mathrm{D}_{2} \mathrm{O}$ and $\mathrm{H}_{2} \mathrm{O}$ (electrolyte: $\mathrm{Na}_{2} \mathrm{SO}_{4}$ anhydrous, $50 \mathrm{mM}$ ). The inset plot shows the KIE values as a function of the potential. (c) LSV curves of poly-1@GC at various phosphate buffer concentrations ([Pi]). The inset plot shows the logarithm of the current density at selected potentials against the logarithm of the phosphate concentration; the slopes of the linear fitting curves reflect the reaction orders in [Pi]. (d) TOF values of poly-1@GC with a catalyst coverage of $5.1 \times 10^{-11} \mathrm{~mol} \mathrm{~cm}^{-2}$, measured by the chronoamperometric method.

of Complex 1 reduced the distance between the catalytic centers of $[\mathrm{Ru}(\mathrm{bda})]$, facilitating the coupling between the two $\mathrm{Ru}^{\mathrm{IV}}-\mathrm{O} \cdot$ radical species $\left(\mathrm{Ru}^{\mathrm{V}}=\mathrm{O}\right)$, which is beneficial for the $\mathrm{I} 2 \mathrm{M}$ pathway. In contrast, in the case of the poly-1+PSt copolymer, polystyrene (acting as blocking unit) would force the catalytic centers to separate at relatively large distances from each other, thereby greatly reducing the probability of the I2M pathway. The comparison between poly-1@GC and poly-1+PSt@GC proves that the $\mathrm{O}-\mathrm{O}$ bond formation pathways for [Ru(bda)] catalysts on the electrode surface can be turned from radical coupling to the APT-assisted WNA mechanism by the introduction of blocking units in the second coordination sphere of the catalyst.

The turnover frequencies (TOFs) of the catalysts on the surface of poly-1@GC and poly-1+PSt@GC were calculated by eqn. S12 (Figs. 2(d) and 3(d); the details can be found in the Supporting Information). Poly-1@GC $\left(2.4 \mathrm{~s}^{-1}\right)$ showed a much higher TOF than poly-1+PSt@GC $\left(0.7 \mathrm{~s}^{-1}\right)$ at the same applied potential of $1.5 \mathrm{~V} v s$. NHE, with similar catalyst coverages (Fig. S6); this indicates that [Ru(bda)], catalyzing water oxidation via the $\mathrm{I} 2 \mathrm{M}$ pathway, can achieve a much faster reaction rate than the WNA pathway.

Next, we measured the $\rho_{\mathrm{cata}}, \rho_{\mathrm{p}}$, and $\mathrm{KIE}_{\mathrm{H} / \mathrm{D}}$ values for poly-1+P3F@GC. The results reveal that the catalyst undergoes a first-order reaction in this system (Fig. 4(a)). This kinetic behavior is similar to that of the poly-1+PSt co-polymer, which does not possess any hydrogen-bonding acceptors, suggesting that a WNA pathway is active for poly-1+P3F. The KIEH/D is greater than 2.2 between 1.1 and $1.4 \mathrm{~V}$ (Fig. 4(b)), indicating the presence of primary isotope effects, as observed for the poly-1+PSt@GC electrode, as well as the occurrence of $\mathrm{O}-\mathrm{H}$ bond cleavage in the RDS. Therefore, the WNA pathway is the favored reaction pathway for poly-1+P3F@GC, similar to poly-1+PSt@GC. However, different from the poly-1+PSt@GC electrode, a zero-order reaction kinetics in phosphate concentration was observed for the poly-1+P3F@GC electrode (Fig. 4(c)), which could be attributed to the dipole environment of the poly-1+P3F@GC system. The dielectric constant of P3F is much higher than that of PSt, and the addition of phosphate will not significantly influence the dipole environment of the system. As a result, the proton transfer in the water attack step is not affected by the added phosphate, compared to the case of 

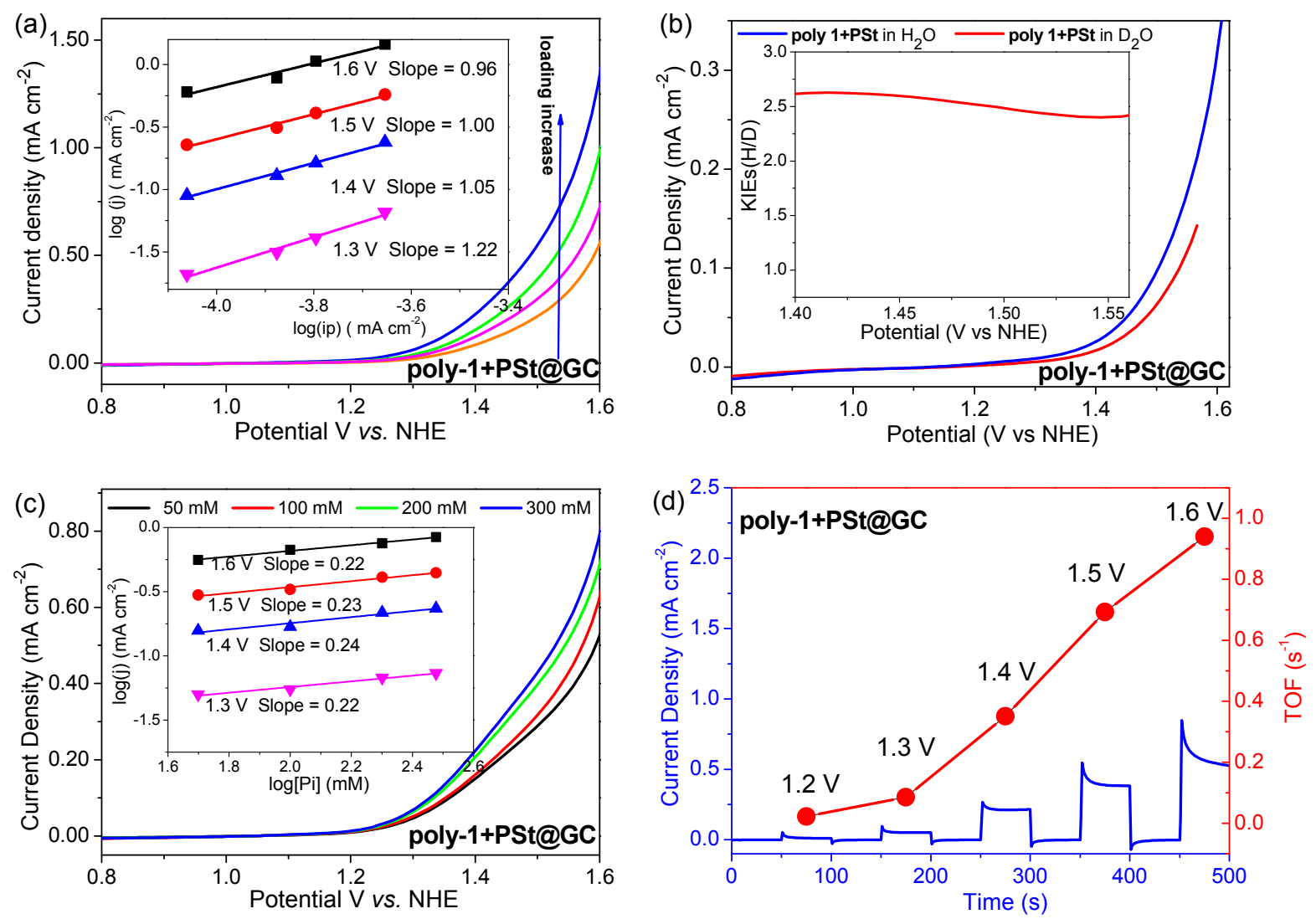

Fig. 3. (a) LSV curves of poly-1+PSt@GC at various catalyst coverages $\Gamma$. The inset plot shows the logarithm of the current density at selected potentials as a function of the logarithm of the corresponding peak current of the $\mathrm{Ru}^{\mathrm{III} / \mathrm{II}}$ couple; the slopes of the linear fitting curves reflect the reaction orders in catalyst coverage ( $\left.\rho_{\Gamma}\right)$. (b) LSV curves of poly-1+PSt@GC in $\mathrm{D}_{2} \mathrm{O}$ and $\mathrm{H}_{2} \mathrm{O}$ (electrolyte: $\mathrm{Na}_{2} \mathrm{SO}_{4}$ anhydrous, 50 mM). The plot inset shows the KIE values as a function of the potential. (c) LSV curves of poly-1+PSt@GC at various phosphate buffer concentrations. The inset plot shows the logarithm of the current density at selected potentials as a function of the logarithm of the phosphate concentration; the slopes of the linear fitting curves reflect the reaction orders in [Pi]. (d) TOF values of poly-1+PSt@GC with a catalyst coverage of $7.2 \times 10^{-11} \mathrm{~mol} \mathrm{~cm}^{-2}$, measured by the chronoamperometric method.

poly-1+PSt@GC.

In poly-1+PSt@GC, with blocking units in the second coordination sphere of the catalyst, the [Ru(bda)] species on the electrode surface catalyzes the water oxidation reaction via a WNA pathway assisted by the APT process. However, in the case of poly-1+P3F@GC, the role of the extra base in the solution APT process is greatly suppressed, which suggests that other functional groups located in the vicinity of the catalytic center serve as additional bases [49]. As the fluorine atoms of $\mathrm{C}\left(s p^{3}\right)-\mathrm{F}$ bonds can serve as hydrogen-bonding acceptors [36-39], and the dielectric constant of trifluoromethyl-4-vinylbenzene is high, such groups located in the vicinity of the $[\mathrm{Ru}(\mathrm{bda})]$ units can facilitate the deprotonation process in the RDS, leading to the reaction rate being independent on the concentration of phosphate in the electrolyte. The trifluoromethyl groups play a similar role to the Tyr160/161 residues in PSII. Such 'smart' removal of protons from the catalytic site during water oxidation contributes to the increased reaction rate and the negative shift of the potential for $\mathrm{Ru}^{\mathrm{V}}=0$ generation.
The TOFs of the catalysts on the surfaces of poly-1+P3F@GC and poly-1+PSt@GC are compared in Figs. 3(d) and 4(d). At a catalyst coverage of $5.6 \times 10^{-11} \mathrm{~mol} \mathrm{~cm}^{-2}$ for poly-1+P3F@GC (Figs. S6(c) and S6(c)'), the TOF of [Ru(bda)] in the P3F-containing co-polymer is $1.2 \mathrm{~s}^{-1}$, greater than that $\left(0.7 \mathrm{~s}^{-1}\right)$ of poly-1+PSt@GC at the same applied potential (1.5 V vs. NHE). These results reveal that the second coordination sphere of the WOCs influences their water oxidation kinetics without changing the first coordination structures.

\section{Conclusions}

In summary, the Pourbaix diagrams of the poly-1@GC, poly-1+P3F@GC, and poly-1+PSt@GC electrodes, prepared by electrochemical polymerization of the $[\mathrm{Ru}(\mathrm{bda})]$ molecular WOC on GC, revealed that the intermediates and redox processes of the molecular catalyst are strongly influenced by the functional groups present in its second coordination spheres, even on the electrode surface. The strong dipole moment of the 4-(trifluoromethyl)-phenyl group can stabilize [Ru(bda)] in- 

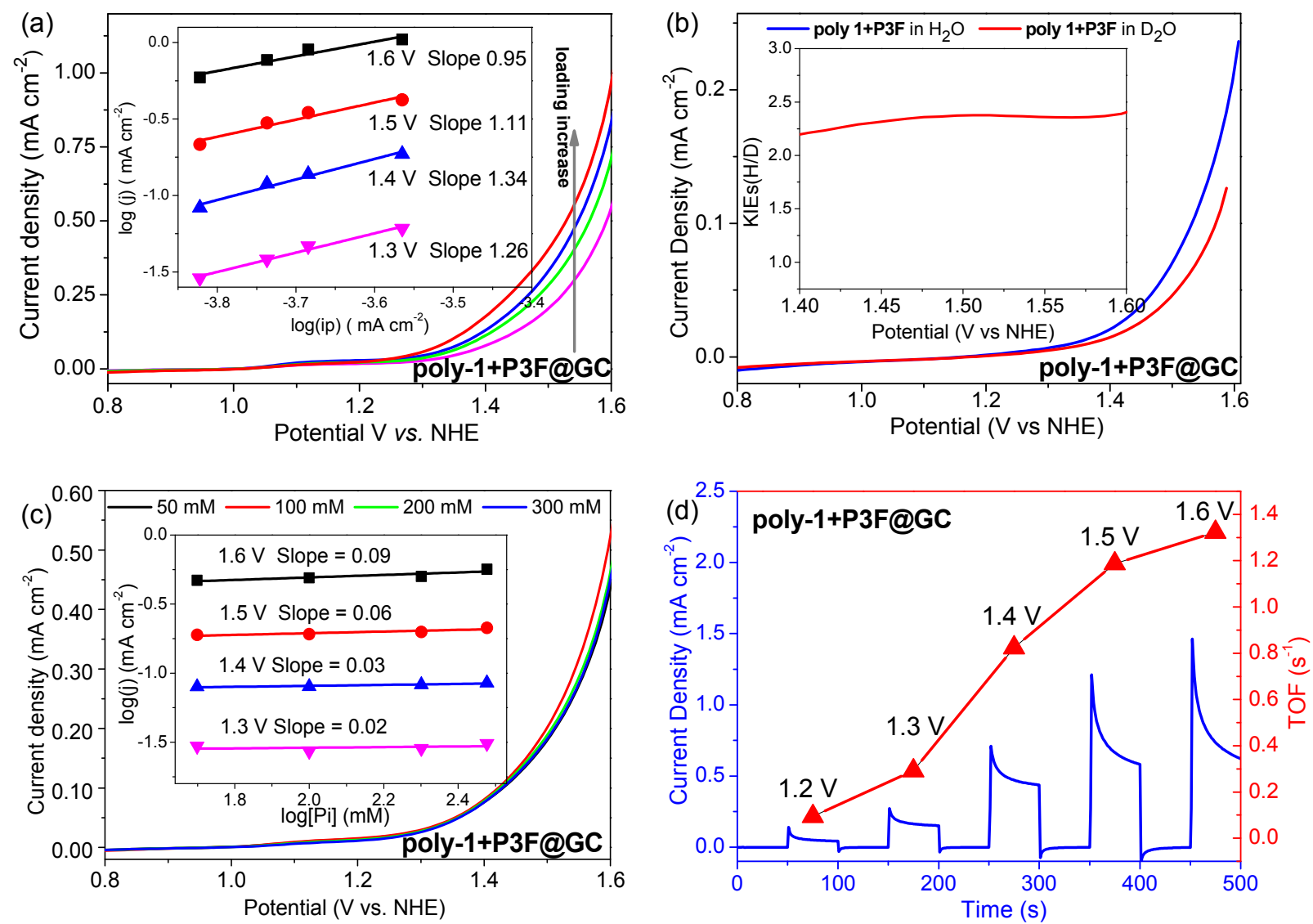

Fig. 4. (a) LSV curves of poly-1+P3F@GC at various catalyst coverages $\Gamma$. The inset plot shows the logarithm of the current density at selected potentials against the logarithm of the corresponding peak current of the $\mathrm{Ru}$ III/II couple; the slopes of the linear fitting curves reflect the reaction orders in catalyst coverage $(\rho \Gamma)$. (b) LSV curves of poly-1+P3F@GC in $\mathrm{D}_{2} \mathrm{O}$ and $\mathrm{H}_{2} \mathrm{O}$ (electrolyte: anhydrous $\mathrm{Na}_{2} \mathrm{SO}_{4}, 50 \mathrm{mM}$ ). The inset shows the $\mathrm{KIE}$ values as a function of the potential. (c) LSV curves of poly-1+P3F@GC at various phosphate buffer concentrations. The inset plot shows the logarithm of the current density at selected potentials as a function of the logarithm of the phosphate concentration; the slopes of the linear fitting curves reflect the reaction orders in [Pi]. (d) TOFs of poly-1+P3F@GC with a catalyst coverage of $5.6 \times 10^{-11} \mathrm{~mol} \mathrm{~cm}^{-2}$, measured by the chronoamperometric method.

termediates with partial charges and negatively shift the redox potential of $\mathrm{Ru}^{\mathrm{V}}=\mathrm{O}$ species, which trigger the $\mathrm{O}-\mathrm{O}$ bond formation. After analyzing the reaction orders of the catalysts, the influence of the phosphate concentration in the electrolyte, and the KIEs of the electrodes for electrochemical water oxidation, we concluded that the poly-1@GC system could still catalyze the electrochemical water oxidation reaction through the radical coupling interaction of two metallo-oxyl radicals, to form the $0-0$ bond. In contrast, the poly-1+PSt and poly-1+P3F systems, containing blocking units, catalyzed water oxidation mainly through the water nucleophilic attack pathway. However, when the 4-(trifluoromethyl)-phenyl group was introduced in the poly-1+P3F co-polymer, the solution APT process was suppressed, while the rate of the reaction proceeding via the water nucleophilic attack pathway increased; this could be attributed to the high dielectric constant and the hydrogen-bonding acceptors of the 4-(trifluoromethyl)-phenyl group in the second coordination sphere of [Ru(bda)]. These results can provide a new avenue for the design and synthesis of advanced water oxidation catalysts on electrode surfaces, in order to achieve superior catalytic activity through second coordination sphere engineering.

\section{Notes}

The authors declare no competing financial interest.

\section{References}

[1] M. W. Kanan, Y. Surendranath, D. G. Nocera, Chem. Soc. Rev., 2009, 38, 109-114.

[2] R. H. Coridan, A. C. Nielander, S. A. Francis, M. T. McDowell, V. Dix, S. M. Chatman, N. S. Lewis, Energy Environ. Sci., 2015, 8, 2886-2901.

[3] J. Hwang, R. R. Rao, L. Giordano, Y. Katayama, Y. Yu, Y. Shao-Horn, Science, 2017, 358, 751-756.

[4] B. Y. Xia, Y. Yan, N. Li, H. B. Wu, X. W. Lou, X. Wang, Nat. Energy, 2016, 1, 15006.

[5] B. A. Pinaud, J. D. Benck, L. C. Seitz, A. J. Forman, Z. Chen, T. G. Deutsch, B. D. James, K. N. Baum, G. N. Baum, S. Ardo, H. Wang, E. Miller, T. F. Jaramillo, Energy Environ Sci., 2013, 6, 1983-2002. 


\section{Graphical Abstract}

Chin. J. Catal., 2021, 42: 460-469 doi: 10.1016/S1872-2067(20)63671-3

Tuning the 0-0 bond formation pathways of molecular water oxidation catalysts on electrode surfaces via second coordination sphere engineering

Qiming Zhuo, Shaoqi Zhan, LeLe Duan, Chang Liu, Xiujuan Wu, Mårten S. G. Ahlquist, Fusheng Li *, Licheng Sun Dalian University of Technology, China; KTH Royal Institute of Technology, Sweden; Southern University of Science and Technology, China
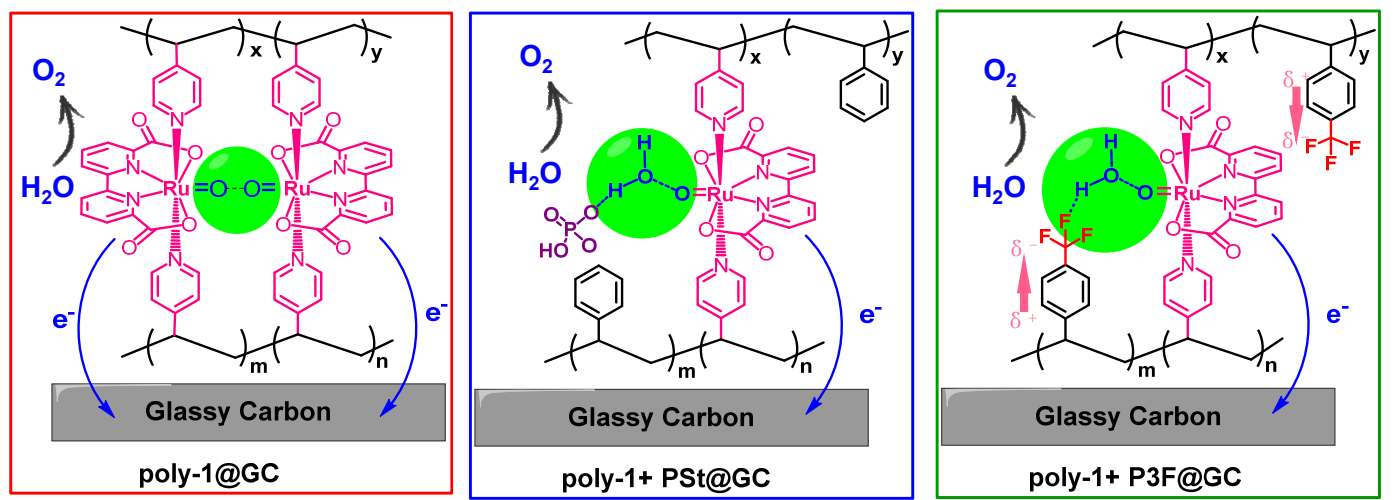

The strong dipole moment in the second coordination sphere of water oxidation catalysts on electrode surfaces can affect the 0-0 bond formation mechanism and enhance the reaction kinetics.

[6] A. Kimoto, K. Yamauchi, M. Yoshida, S. Masaoka, K. Sakai, Chem. Commun., 2012, 48, 239-241.

[7] S. Haschke, M. Mader, S. Schlicht, A. M. Roberts, A. M. Angeles-Boza, J. A. C. Barth, J. Bachmann, Nat. Commun., 2018, 9, 4565.

[8] Z. W. Seh, J. Kibsgaard, C. F. Dickens, I. Chorkendorff, J. K. Nörskov, T. F. Jaramillo, Science, 2017, 355, eaad4998.

[9] M. D. Kärkäs, O. Verho, E. V. Johnston, B. Åkermark, Chem. Rev., 2014, 114, 11863-12001.

[10] D. W. Shaffer, Y. Xie, J. J. Concepcion, Chem. Soc. Rev., 2017, 46, 6170-6193.

[11] T. J. Meyer, M. V. Sheridan, B. D. Sherman, Chem. Soc. Rev., 2017, 46, 6148-6169.

[12] S. Ghosh, M.-H. Baik, Angew. Chem. Int. Ed., 2012, 51, 1221-1224.

[13] S. W. Gersten, G. J. Samuels, T. J. Meyer, J. Am. Chem. Soc., 1982, 104, 4029-4030.

[14] L. L. Duan, L. Wang, F. S. Li, F. Li, L. C. Sun, Acc. Chem. Res., 2015, 48, 2084-2096.

[15] N. Wang, H. Q. Zheng, W. Zhang, R. Cao, Chin. J. Catal., 2018, 39, 228-244.

[16] H. Li, X. L. Li, H. T. Lei, G. J. Zhou, W. Zhang, R. Cao, ChemSusChem, 2019, 12, 801-806.

[17] L. S. Xie, X. L. Li, B. Wang, J. Meng, H. T. Lei, W. Zhang, R. Cao, Angew. Chem. Int. Ed., 2019, 58, 18883-18887.

[18] Y. Umena, K. Kawakami, J.-R. Shen, N. Kamiya, Nature, 2011, 473, $55-60$.

[19] M. Suga, F. Akita, K. Hirata, G. Ueno, H. Murakami, Y. Nakajima, T. Shimizu, K. Yamashita, M. Yamamoto, H. Ago, J.-R. Shen, Nature, 2014, 517, 99-103.

[20] H. Dau, M. Haumann, Biochim. Biophys. Acta, Bioenerg., 2007, $1767,472-483$.

[21] Z. F. Chen, J. J. Concepcion, X. Q. Hu, W. T. Yang, P. G. Hoertz, T. J. Meyer, Proc. Natl. Acad. Sci. USA, 2010, 107, 7225.

[22] T. J. Meyer, M. H. V. Huynh, H. H. Thorp, Angew. Chem. Int. Ed.,
2007, 46, 5284-5304.

[23] H. Dau, C. Limberg, T. Reier, M. Risch, S. Roggan, P. Strasser, ChemCatChem, 2010, 2, 724-761.

[24] S. Taneva, M. Busheva, I. Petkanchin, J. Photochem. Photobiol. B, 1991, 10, 315-327.

[25] A. G. Dobrikova, A. G. Ivanov, R. Morgan, I. B. Petkanchin, S. G. Taneva, J. Photochem. Photobiol. B, 2000, 57, 33-40.

[26] A. Gelzinis, D. Abramavicius, J. P. Ogilvie, L. Valkunas, J. Chem. Phys., 2017, 147, 115102.

[27] F. S. Li, K. Fan, L. Wang, Q. Daniel, L. L. Duan, L. C. Sun, ACS Catal,, 2015, 5, 3786-3790.

[28] D. L. Ashford, B. D. Sherman, R. A. Binstead, J. L. Templeton, T. J. Meyer, Angew. Chem. Int. Ed., 2015, 54, 4778-4781.

[29] L. L. Duan, A. Fischer, Y. H. Xu, L. C. Sun, J. Am. Chem. Soc., 2009, 131, 10397-10399.

[30] L. L. Duan, C. M. Araujo, M. S. G. Ahlquist, L. C. Sun, Proc. Natl. Acad. Sci. USA, 2012, 109, 15584-15588.

[31] L. L. Duan, F. Bozoglian, S. Mandal, B. Stewart, T. Privalov, A. Llobet, L. C. Sun, Nat. Chem., 2012, 4, 418-423.

[32] Y. Jiang, F. Li, B. B. Zhang, X. N. Li, X. H. Wang, F. Huang, L. C. Sun, Angew. Chem. Int. Ed., 2013, 52, 3398-3401.

[33] L. Wang, L. L. Duan, Y. Wang, M. S. G. Ahlquist, L. C. Sun, Chem. Commun., 2014, 50, 12947-12950.

[34] S. H. Northrup, J. D. Smith, J. O. Boles, J. C. L. Reynolds, J. Chem. Phys., 1986, 84, 5536-5544.

[35] J. W. van Leeuwen, F. J. M. Mofers, E. C. I. Veerman, Biochim. Biophys. Acta, Bioenerg., 1981, 635, 434-439.

[36] J. A. K. Howard, V. J. Hoy, D. O'Hagan, G. T. Smith, Tetrahedron, 1996, 52, 12613-12622.

[37] J.-F. Paquin, P. Champagne, J. Desroches, Synthesis, 2014, 47, 306-322.

[38] R. A. Cormanich, M. P. Freitas, C. F. Tormena, R. Rittner, RSC Adv., 2012, 2, 4169.

[39] G. T. Giuffredi, V. Gouverneur, B. Bernet, Angew. Chem. Int. Ed., 
2013, 52, 10524-8.

[40] Q. Daniel, P. Huang, T. Fan, Y. Wang, L. L. Duan, L. Wang, F. S. Li, Z. Rinkevicius, F. Mamedov, M. S. G. Ahlquist, S. Styring, L. C. Sun, Coord. Chem. Rev., 2017, 346, 206-215.

[41] A. A. Maryott, E. R. Smith, Table of dielectric constants of pure liquids. U.S. Govt. Print. Off.: Washington, 1951.

[42] D. Moonshiram, V. Purohit, J. J. Concepcion, T. J. Meyer, Y. Pushkar, Materials, 2013, 6, 392-409.

[43] H. Yamada, W. F. Siems, T. Koike, J. K. Hurst, J. Am. Chem. Soc., 2004, 126, 9786-9795.

[44] F. Liu, J. J. Concepcion, J. W. Jurss, T. Cardolaccia, J. L. Templeton, T.
J. Meyer, Inorg. Chem., 2008, 47, 1727-1752.

[45] L. I. Krishtalik, Biochim. Biophys. Acta, Bioenerg., 2000, 1458, 6-27.

[46] F. A. Carey, R. J. Sundberg, Advanced Organic Chemistry: Part A: Structure and Mechanisms. Springer: 2007.

[47] M. Hirahara, S. Nagai, K. Takahashi, K. Saito, T. Yui, M. Yagi, Inorg. Chem., 2015, 54, 7627-7635.

[48] C. Costentin, M. Robert, J. -M. Savéant, J. Am. Chem. Soc., 2007, 129, 5870-5879.

[49] W. L. Li, F. S. Li, H. Yang, X. J. Wu, P. L. Zhang, Y. Shan, L. C. Sun, Nat. Commun., 2019, 10, 5074.

\title{
电极表面第二配位环境对水氧化分子催化剂O-O键形成机理的调控
}

\author{
卓启明 ${ }^{\mathrm{a}, \mathrm{\dagger}}$ ，詹绍琦 ${ }^{\mathrm{b}+}$ ，段乐乐 ${ }^{\mathrm{a}, \mathrm{c}}$ ，刘 畅 ${ }^{\mathrm{a}}$, 吴秀娟 ${ }^{\mathrm{a}}$, Mårten S. G. Ahlquist ${ }^{\mathrm{b}}$, 李福胜 ${ }^{\mathrm{a}}{ }^{*}$, 孙立成, ${ }^{\mathrm{a}, \mathrm{d}}$ \\ ${ }^{\mathrm{a}}$ 大连理工大学精细化工国家重点实验室人工光合作用研究所, 辽宁大连116024, 中国

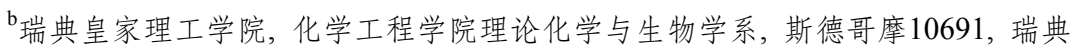 \\ ${ }^{\mathrm{c}}$ 南方科技大学化学, 系格拉布斯研究院, 广东深圳518055, 中国 \\ 瑞典皇家理工学院, 化学工程学院化学系, 斯德哥摩10044, 瑞典
}

\begin{abstract}
摘要: 水氧化反应可以提供四个电子和四个质子, 反应产物是可以资源化的氧气, 因而, 水氧化反应是大规模能源转化和 存储技术理想的阳极反应. 但是, 由于水氧化反应具有较高的热力学能垒, 涉及四个电子和四个质子的转移过程以及氧-氧 键 $(\mathrm{O}-\mathrm{O})$ 的形成, 是一个耗能高且动力学缓慢的复杂反应. 因此, 开发高效的水氧化催化剂来加速水氧化反应速率, 对于能 源转化和存储相关技术至关重要. 然而, 人们对水氧化催化剂的合理设计和在催化反应中提高反应活性的方法了解甚少, 在温和条件下促进 $\mathrm{O}-\mathrm{O}$ 键的有效形成仍然是一个根本性的挑战. 迄今为止, 关于水氧化分子催化剂的研究主要集中在催化 剂的配位结构(第一配位环境)和催化效率之间的关系上, 水氧化分子催化剂的第二配位环境对其催化活性的影响尚未得到 充分研究. 将催化剂引入到电极表面时, 其催化环境和均相反应时完全不同. 因此, 水氧化催化剂在电极表面的催化反应 动力学、质子耦合电子转移过程以及其O-O键形成机理可能发生改变.

本文以4-乙烯基吡啶为轴向配体的 $[\mathrm{Ru}(\mathrm{bda})]$ (络合物 $1, \mathrm{bda}=2,2^{\prime}$-联吡啶- $6,6^{\prime}$-二羧酸)水氧化分子催化剂, 通过电化学 聚合的方法将络合物1固载在玻璃碳电极表面, 用于研究第二配位环境对电极表面水氧化分子催化剂催化机理的影响. 通 过直接聚合络合物 1 在玻璃碳表面得到电极材料poly-1@GC; 将4-三氟甲基苯乙烯和苯乙烯作为限制单元分别与络合物1 共聚, 得到电极材料poly-1+P3F@GC和poly-1+PSt@GC. 通过一系列电极表面动力学方法和DFT计算分别求出催化剂在三 种电极材料中的反应级数 $\rho_{\mathrm{cata}}$ 、催化剂的溶液质子-原子转移性质、催化剂的水氧化氞动力学同位素效应 $\mathrm{KIES}_{\mathrm{H} \mathrm{ID}}$, 以及 $[R u(b d a)]$ 催化剂在不同材料中的偶极矩的变化.

通过对比催化剂在不同电极材料中的催化行为和相关关键参数发现, 电极表面催化剂的第二层配位环境对其水氧化 反应过程中的O-O键形成机制和质子耦合电子转移过程有着显著的影响. [Ru(bda)]在直接聚合的电极材料poly-1@GC中, 通过自由基耦合机理(I2M)形成O-O键. 而当 $[\mathrm{Ru}(\mathrm{bda})]$ 与4-三氟甲基苯乙烯和苯乙烯共聚时, 由于 $[\mathrm{Ru}(\mathrm{bda})]$ 催化剂被分散, 不利于自由基耦合机理的发生, $[\mathrm{Ru}(\mathrm{bda})]$ 在电极材料poly-1+P3F@GC和poly-1+PSt@GC中主要通过水分子亲核进攻机理 进行(WNA)催化水氧化. 同时, 具有强偶极矩的4-三氟甲基苯基能够稳定 $[\mathrm{Ru}(\mathrm{bda})]$ 在催化过程的中间体, 可以使引发 $\mathrm{O}-\mathrm{O}$ 键生成的关键物种 $\mathrm{Ru}^{\mathrm{v}}=\mathrm{O}$ 的氧化电位发生明显的负向移动, 使得 $[\mathrm{Ru}(\mathrm{bda})]$ 在poly-1+P3F $@ G C$ 可以更容易触发水氧化反应, 进而加快了 $[\mathrm{Ru}(\mathrm{bda})]$ 采用水分子亲核进攻机理时的催化反应速率.
\end{abstract}

关键词: 水氧化催化剂; 第二配位环境; 偶极矩; $\mathrm{O}-\mathrm{O}$ 键形成; 反应动力学

收稿日期: 2020-05-09. 接受日期: 2020-06-15. 出版日期: 2021-03-05.

*通讯联系人. 电话/传真: (0411)84986494; 电子信箱: fusheng@dlut.edu.cn

十共同第一作者.

基金来源：大连理工大学基本科研业务费(DUT19LK16); 国家自然科学基金(21120102036, 91233201, 21771098, 2014CB239402); 精细化工重点实验室开放课题(KF1802); 瑞典研究理事会(2017-00935); 瑞典能源署.

本文的电子版全文由Elsevier出版社在ScienceDirect上出版(http://www.sciencedirect.com/science/journal/18722067). 